\title{
METALS RECOVERY FROM ACID MINE DRAINAGE
}

\author{
ALENA LUPTAKOVA ${ }^{1}$, MAGDALENA BALINTOVA ${ }^{2}$, \\ JANA JENCAROVA ${ }^{1}$, EVA MACINGOVA ${ }^{1}$, \\ MARIA PRASCAKOVA ${ }^{1}$ \\ ${ }^{1}$ Department of Mineral Biotechnologies, Institute of Geotechnics of the Slovak \\ Academy of Sciences, Watsonova 45, Košice, SK-043 53, Slovak Republic \\ (luptakal@saske.sk,jencarova@saske.sk,macingova@saske.sk,prascak@saske.sk) \\ ${ }^{2}$ Institute of Building and Environmental Engineering, Civil Engineering Faculty, \\ Technical University of Košice, Vysokoškolská 4, Košice, SK-042 00, Slovak Republic \\ (magdalena.balintova@tuke.sk)
}

\begin{abstract}
The objectives of the present work give the results view of some physicochemical, chemical and biological-chemical methods for the heavy metals removal from Acid Mine Drainage (AMD). The background of the studied physicochemical methods was the adsorption by turf, chemical methods the heavy metals precipitation by the neutralization with $\mathrm{NaOH}$. The principles of the biological-chemical methods were the bioprecipitation by the applications of sulphate-reducing bacteria (SRB), the sorption by the bacterially produced iron sulphides and sorption by brown coal bio-modified by micromycetes.
\end{abstract}

Key words: Acid Mine Drainage, neutralization, bioprecipitation, sorption, biosorption

\section{Introduction}

Acid Mine Drainage (AMD) is unique among industrial contaminants on the subject of mainly the mining industry of the sulphide minerals. AMD generation proceeds increased considerably after the closure of mines. Acid mine waters have low $\mathrm{pH}$-values, and typically high concentrations of sulphates, iron and non-ferrous metals (KONTOPOULOS, 1988), which serve as buffering systems. Development of cost-effective and sustainable remediation solutions for the mine water problem has been the subject of extensive review. In addition to monitored natural attenuation, the two broad philosophies which have been pursued in the treatment and abatement of mine water pollution include measures directed towards prevention at source, usually involving physical intervention of one form or another, and measures directed at the resulting effluent, including active or passive remedial systems. Both active and passive systems may be implemented using physicochemical, chemical or biological-chemical treatment technologies (SKOUSEN et al., 1998; KADUKOVA and STOFKO, 2006a).

Nowadays is pay attention to physical, chemical and biological methods for the selective recovery of metals from AMD. These methods constitute the possibility of the recovery metals in the suitable forms for commercial value. Current research of heavy metals removal in water environment is aimed to application of natural materials as well as industrial wastes that are regarded as cost effective sorbents 
(GARCIA SANCHEZ et al. 1999). Among the most often tested sorbents of heavy metals belong: zeolite, carbonate, clays, turf, oxide and hydroxide of iron. DEORKAR and TAVLARIDES (1998) development of AMD physicochemical treatment by application of an adsorption process comprised of inorganic chemically active adsorbents to selectively recover of $\mathrm{Fe}, \mathrm{Cu}, \mathrm{Zn}, \mathrm{Cd}$ and $\mathrm{Pb}$ from $\mathrm{AMD}$ without neutralization. JACKE and DIEBOLD (1983) evaluated the chemical treatment of AMD on the ground of metal recovery from AMD by addition of sulphides followed by oxidation and selective titration. $\mathrm{Cu}$ and $\mathrm{Zn}$ precipitated as sulphides and $\mathrm{Fe}, \mathrm{Al}, \mathrm{Mn}$ and $\mathrm{Mg}$ were recovered as hydroxides. TABAK et al. (2003) conducted the biotreatment of AMD by selective sequential precipitation to recover metals as hydroxides and sulphides. For the metals removal from AMD can be used different biosorbents on the base of sawdust, algae, microscopic fungi, biogenous ferrous sulphides biomass and etc. (KADUKOVA and STOFKO, 2006b; KADUKOVA and VIRCIKOVA, 2003).

In Slovak Republic there are some localities with existing AMD generation conditions. Our previous research demonstrates the AMD critical values in the abandoned $\mathrm{Cu}-\mathrm{Fe}$ ore deposit Smolnik (LUPTAKOVA et al., 2006). It is necessary to develop methods for their treatment. That was the reason for starting a systematic monitoring of geochemical development in acid mine drainage in 2004 in order to prepare a prognosis in terms of environmental risk and use of these waters as an atypical source of a wide range of elements.

On this account was our research oriented on the development suitable methods or their combination for the AMD effluent treatment from deposit Smolnik. We studied some physicochemical, chemical and biological-chemical methods. Heavy metals model solutions and AMD from Smolnik were used for experiments. The background of the used physicochemical methods was the adsorption by turf brush Peatsorb. Experiments of the chemical methods were oriented on to study of the metals selective precipitation in the hydroxides form by the neutralization with $\mathrm{NaOH}$. The principle was the endpoint titration. The backgrounds of the biological-chemical methods were the bioprecipitation by the applications of sulphate-reducing bacteria (SRB), the sorption by the bacterially produced iron sulphides and sorption by brown coal modified by different micromycetes strains. The metabolic process of SRB is the anaerobic reduction of sulphates by the formation of hydrogen sulphide reacting in the water with cations of metals forming little soluble sulphides. Investigated was the process of the heavy metals precipitation by bacterially produced hydrogen sulphide with the combination of the metals precipitation by sodium hydroxide at the various AMD $\mathrm{pH}$ values. In the literature this methods is named as the selective sequential precipitation (SSP) (TABAK et al., 2003). Besides SRB application gives rise to Fe sulphides $\left(\mathrm{Fe}_{\mathrm{x}} \mathrm{S}_{\mathrm{y}}\right)$ with the magnetic properties, which are suitable bio-sorbents of heavy metals and are utilizable for AMD treatment in combination with the magnetic separation. For the heavy metals removal from solutions also unconventional sorbents prepared from brown coal by micromycetes were used. It was studied bio-modification of brown coal sorption materials with the aim to enhance its sorption properties. The micromycetes (Aspergillus niger, Aspergillus clavatus, 
Penicillium glabrum and Trichoderma viride) have been selected for biological activation of coal samples.

\section{Material and methods}

\subsection{Model solutions}

Stock solutions of each metal: Cu(II) containing 30-300 mg/L, Zn(II) containing 30-300 mg/L and $\mathrm{Cd}(\mathrm{II})$ containing $50-100 \mathrm{mg} / \mathrm{L}$ were prepared by dissolving $\mathrm{CuSO}_{4} \cdot 5 \mathrm{H}_{2} \mathrm{O}, \mathrm{ZnSO}_{4} \cdot \mathrm{H}_{2} \mathrm{O}$ and $3 \mathrm{CdSO}_{4} \cdot 8 \mathrm{H}_{2} \mathrm{O}$ of analytical grade in distilled water.

\subsection{Acid mine drainage}

The experiments were conducted with AMD coming from the abandoned and flooded deposit of Smolnik (Slovak Republic). The average values of $\mathrm{pH}$ and the major metals composition of acid mine drainage was following: $\mathrm{pH} 3.9, \mathrm{SO}_{4}{ }^{2-}$ 2938 mg/L, Fe - 307 mg/L, Mn - 26 mg/L, Cu - 5 mg/L, Zn - 11 mg/L, Al - 77 mg/L.

\subsection{Adsorption metals by turf}

Based on our previous results, where various adsorbents were tested (BALINTOVA and KOVALIKOVA, 2008) for our study of $\mathrm{Cu}, \mathrm{Fe}, \mathrm{Al}, \mathrm{Zn}$ ions removal from acid mine drainage by adsorption, turf brush PEATSORB (REO AMOS Slovakia) was used. The dependence of $\mathrm{Cu}, \mathrm{Fe}, \mathrm{Al}, \mathrm{Zn}$ concentration decreasing on time (1, 3, 5 and $10 \mathrm{~min}$ ), was investigated under dynamic conditions using turf brush PEATSORB. To intensify the adsorption process, sample of AMD was continuously stirred with $5 \mathrm{~g}$ of turf brush PEATSORB. In filtrate was determined $\mathrm{pH}$ (METTLER TOLEDO) and Cu, Fe, Al, Zn by colorimeter DR 890 (HACH LANGE).

\subsection{Metals precipitation by $\mathrm{NaOH}$}

The precipitation by $1 \mathrm{M} \mathrm{NaOH}$ solutions was used for the removal of metals as hydroxides from AMD. Experiments were carried out by raw AMD samples of $100 \mathrm{~mL}$ and each were titrated to $\mathrm{pH}$ end points ranging from 5 to 9 using $1 \mathrm{M}$ $\mathrm{NaOH}$. When the preset $\mathrm{pH}$ end point was reached, the titrated solution was filtered to precipitated metals removing. During titration the AMD solution was continuously stirred, the $\mathrm{pH}$ was monitored and the concentration of metals was determined too.

\subsection{Metals precipitation by biogenic $\mathrm{H}_{2} \mathrm{~S}$ and $\mathrm{NaOH}$}

For the production of the bacterially $\mathrm{H}_{2} \mathrm{~S}$ the cultures of SRB (genera Desulfovibrio) were used. These bacteria were isolated from a mixed culture obtained from the potable mineral water (Gajdovka spring, the locality Kosice-north, Slovakia). 
This biological-chemical method contains several process steps and can be divided in to these main steps, as well as: the bacterially $\mathrm{H}_{2} \mathrm{~S}$ production by SRB; the heavy metals precipitation by the bacterially produced $\mathrm{H}_{2} \mathrm{~S}$; the heavy metal sulphides separation by the filtration; the setting $\mathrm{pH}$ of the filtrate from previous steps by $1 \mathrm{M}$ $\mathrm{NaOH}$ (the precipitation of metals as hydroxides); the heavy metal hydroxides separation by the filtration; the subsequent precipitation of the heavy metals by bacterially produced $\mathrm{H}_{2} \mathrm{~S}$. Values of $\mathrm{pH}$ for the heavy metals precipitation were assigned on the ground of the study of the orientation conditions for the selected metal removal from AMD by precipitation using $\mathrm{NaOH}$ and our previous works and enumerations (LUPTAKOVA et al., 2003). The concentration of metals was determined by atomic absorption spectrometry using Spectrometer AA-30 Varian instrument. A glass $\mathrm{pH}$ electrode combined with the reference Ag/AgCl electrode was used to measure pH. Digital pH- meter GPRT 144 AGL was used.

\subsection{Sorption of metals by bacterially produced iron sulphides}

The preparation of biogenic sulphides was realized in the bioreactor filled with $400 \mathrm{~mL}$ of modified nutrient medium DSM-63 and inoculated with $100 \mathrm{~mL}$ of a culture of SRB during 21 days at $30^{\circ} \mathrm{C}$ under anaerobic conditions. These conditions were generated by introducing an inert gas $\left(\mathrm{N}_{2}\right)$ and chemically with sodium thioglycolate. The $\mathrm{pH}$ of the medium was adjusted to the value 6.8 with sodium hydroxide. Preparation was realized under 2 different modes. During discontinuous mode the bioreactor worked without addition of fresh nutrient medium. During semicontinuous process of preparation the bioreactor worked 4 days in batch mode and then 3 days in continuous mode (i.e. fresh medium was supplied into reactor). Batch sorption experiments were performed in $100 \mathrm{~mL}$ Erlenmeyer flasks with the sorbent dose $1 \mathrm{~g} / \mathrm{L}$. Sampling was conducted during 90 minutes. The concentration of zinc and cadmium was determined by atomic absorption spectrometry.

\subsection{Sorption by bio-modified brown coal}

The cultures of selected micromycetes were grown in Sabouraud agar medium. Suspension was injected (5 mL) of every 14-day-old culture spores in SAB to the $10 \mathrm{~g}$ of brown coal mixed with $10 \mathrm{~mL}$ of SAB medium. The cultivation was executed in the dark at ambient temperature. The leaching process took 7 weeks. After leaching, the suspensions were filtered, washed with distilled water, dried and prepared for adsorption experiments. All the adsorption experiments were conducted at ambient temperature in a laboratory shaker. Metal solutions of known concentrations were introduced into the glass Erlenmeyer bottles containing defined amounts (10 g/L) of the adsorbent. The bottles were shaken horizontally and the adsorbent was removed by filtration after 1 hour adsorption. The equilibrium concentrations of heavy metals were determined by atomic adsorption spectroscopy and the metal uptake was calculated from the difference. The Langmuir adsorption isotherms have been constructed and the maximum adsorption capacity of the adsorbents has been 
determined. For $\mathrm{Cu}(\mathrm{II})$ sorption the $\mathrm{pH}$ reached 5 , as $\mathrm{Cu}(\mathrm{II})$ ions undergo hydrolysis reactions in water and form insoluble aqueous complexes with increasing $\mathrm{pH}$. Zn(II) sorption experiments were performed at $\mathrm{pH} 7$ for the same reason as in case of $\mathrm{Cu}(\mathrm{II})$ adsorption.

\section{Results and discussion}

\subsection{Adsorption metals by turf}

Table 1 documents the physical-chemical method studies and there are also given the results of $\mathrm{pH}$ measuring in AMD - turf brush mixture depending on time and influence of adsorption processes on $\mathrm{Cu}, \mathrm{Fe}, \mathrm{Al}, \mathrm{Zn}$ concentrations in individual samples. From the results follows, that it is possible to decrease the $\mathrm{Cu}, \mathrm{Fe}, \mathrm{Al}$ and $\mathrm{Zn}$ concentrations in polluted surface water by physical adsorption. The highest turf brush efficiency was observed for zinc removal, where the decrease of concentration in solution was 95.71\%. Then follows copper (decreasing in AMD about 55.88\%), iron (21.19\%) and aluminium (15.6\%). Based on experimental results we can also state that chosen adsorbent have not influenced the $\mathrm{pH}$ increasing above 4 that is connected with precipitation of metals.

Table 1. Dependence of $\mathrm{Cu}, \mathrm{Fe}, \mathrm{Al}$ and $\mathrm{Zn}$ removal from AMD versus adsorption time.

\begin{tabular}{cccccc}
\hline Adsorption time & $\mathrm{pH}$ & $\mathrm{Cu}$ & $\mathrm{Fe}$ & $\mathrm{Al}$ & $\mathrm{Zn}$ \\
\cline { 3 - 6 } & & \multicolumn{5}{c}{$[\mathrm{mg} / \mathrm{L}]$} \\
\hline AMD & 3.95 & 1.36 & 358.2 & 54.5 & 17.5 \\
$1 \mathrm{~min}$ & 3.10 & 0.86 & 347.8 & 52.7 & 1.5 \\
$3 \mathrm{~min}$ & 2.95 & 0.61 & 353.3 & 46.4 & 1.2 \\
$5 \mathrm{~min}$ & 2.97 & 0.61 & 333.5 & 46.2 & 1.0 \\
$10 \mathrm{~min}$ & 2.93 & 0.60 & 282.3 & 46.0 & 0.75 \\
\hline
\end{tabular}

\subsection{Metals precipitation by $\mathrm{NaOH}$}

The results of the titration test AMD by $0.2 \mathrm{M} \mathrm{NaOH}$ documents Fig. 1 . It is a documentation of the titration curve and elemental AMD analysis. The titration curve of AMD can be divided into a number of by its different slopes. It shows that the optimum $\mathrm{pH}$ for metals precipitation is different for each metal: for $\mathrm{Al}-\mathrm{pH} 5$; for $\mathrm{Cu}-\mathrm{pH}$ 6; for $\mathrm{Zn}-\mathrm{pH} 7$; for $\mathrm{Fe}-\mathrm{pH}$ 8; for $\mathrm{Mn}-\mathrm{pH} 9$.

Table 3 demonstrates results of metals precipitation by $\mathrm{NaOH}$ that is titration of AMD to $\mathrm{pH}$ end points for the individual metals ranging from 5 to 9 using $1 \mathrm{M}$ $\mathrm{NaOH}$. As it is seen from Table 2 was removed $97 \%$ of $\mathrm{Al}$ at $\mathrm{pH} 5 ; 99.9 \%$ of $\mathrm{Cu}$ at $\mathrm{pH}$ 6; 99.9\% of $\mathrm{Zn}$ at $\mathrm{pH} 7 ; 99.9 \%$ of $\mathrm{Fe}$ at $\mathrm{pH} 8$ and $99.9 \%$ of $\mathrm{Mn}$ at $\mathrm{pH}$ 9. Initial assumption about precipitation of followed metals up to $\mathrm{pH} 9$ has been confirmed. 


\subsection{Metals precipitation by biogenic $\mathrm{H}_{2} \mathrm{~S}$ and $\mathrm{NaOH}$}

The selective sequential precipitation of heavy metals form AMD sample was performed in two interconnected bioreactors with a capacity $1000 \mathrm{~mL}$ (the first bioreactor) and $250 \mathrm{~mL}$ (the second bioreactor), which operated at the semi-continual conditions. Using the operating conditions and obtained results of the selective sequential precipitation of heavy metals form AMD sample illustrated in Table 3. The bacterially produced hydrogen sulphide by SRB at pH 3.9 (initial pH of AMD), 4.5 and 6.0 realized the selective sequential precipitation of $\mathrm{Cu}, \mathrm{Zn}$ and $\mathrm{Fe}$, respectively (i.e. steps 1,3 and 5 ). $\mathrm{Al}$ and $\mathrm{Mn}$ were precipitated as aluminium and manganese hydroxide at $\mathrm{pH} 6.0$ and 9.0, respectively (i.e. steps 4 and 6). Fe was precipitated predominantly as hydroxide (steps 2, 4 and 6).

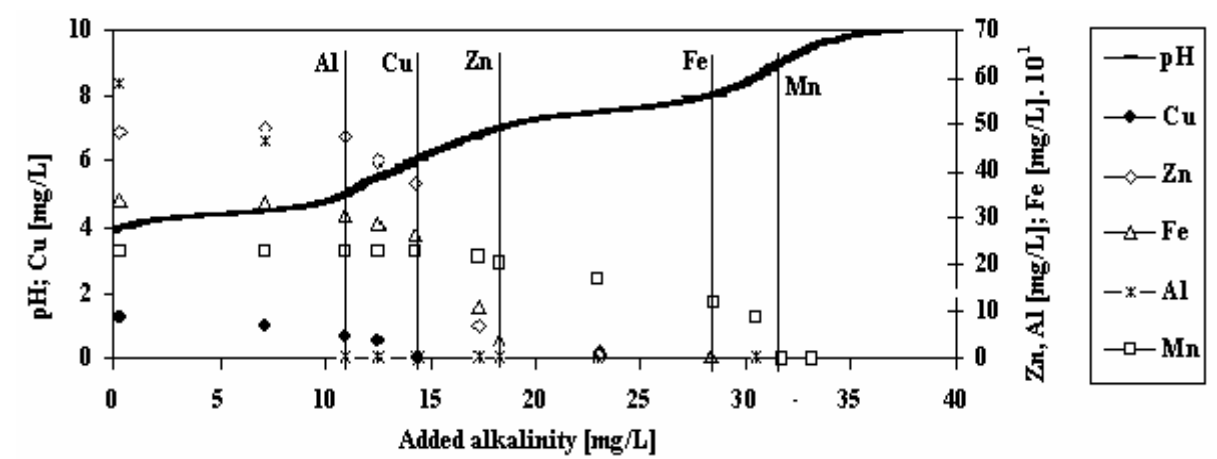

Fig. 1. Titration curve and metal AMD analysis of AMD from the deposit of Smolnik.

Table 2. Precipitation of Al, Cu, $\mathrm{Zn}, \mathrm{Fe}$ and $\mathrm{Mn}$ in $\mathrm{pH}$ dependence (initial pH of AMD - 3.9).

\begin{tabular}{cccccc}
\hline $\mathrm{pH}$ & $\mathrm{Al}(\mathrm{mg} / \mathrm{L})$ & $\mathrm{Cu}(\mathrm{mg} / \mathrm{L})$ & $\mathrm{Zn}(\mathrm{mg} / \mathrm{L})$ & $\mathrm{Fe}(\mathrm{mg} / \mathrm{L})$ & $\mathrm{Mn}(\mathrm{mg} / \mathrm{L})$ \\
\hline 3.9 & 58.8 & 1.38 & 6.88 & 338.6 & 22.88 \\
5 & $\mathbf{0 . 4}$ & 0.65 & 6.75 & 268.8 & 22.88 \\
6 & 0.4 & $<\mathbf{0 . 0 2}$ & 5.38 & 9.8 & 22.88 \\
7 & 0.4 & $<0.02$ & $<\mathbf{0 . 0 3}$ & 2.5 & 20.38 \\
8 & 0.4 & $<0.02$ & $<0.03$ & $<\mathbf{0 . 0 3}$ & 12.25 \\
9 & 0.4 & $<0.02$ & $<0.03$ & $<0.03$ & $\mathbf{0 . 0 3}$ \\
\hline
\end{tabular}

Table 3. Metals precipitation by bacterially produced $\mathrm{H}_{2} \mathrm{~S}$ and $\mathrm{NaOH}$ (initial AMD $\mathrm{pH}-3.9$ ).

\begin{tabular}{|c|c|c|c|c|c|c|}
\hline & Step 1. & Step 2. & Step 3. & Step 4. & Step 5. & Step 6. \\
\hline$\overline{\mathrm{pH}}$ & 3.9 & 4.5 & 4.5 & 6.0 & 6.0 & 9.0 \\
\hline Precipitating agent & $\mathrm{H}_{2} \mathrm{~S}$ & $\mathrm{NaOH}$ & $\mathrm{H}_{2} \mathrm{~S}$ & $\mathrm{NaOH}$ & $\mathrm{H}_{2} \mathrm{~S}$ & $\mathrm{NaOH}$ \\
\hline Removed metals & $\mathrm{Cu}$ & $\mathrm{Fe}, \mathrm{Al}$ & $\mathrm{Zn}$ & $\mathrm{Al}, \mathrm{Fe}$ & $\mathrm{Fe}$ & $\mathrm{Mn}, \mathrm{Fe}$ \\
\hline $\begin{array}{c}\text { Form of removed } \\
\text { metals } \\
\text { (solid phase) }\end{array}$ & $\mathrm{CuS}$ & $\begin{array}{l}\mathrm{Fe}(\mathrm{OH})_{3} \\
\mathrm{Al}(\mathrm{OH})_{3}\end{array}$ & $\mathrm{ZnS}$ & $\begin{array}{l}\mathrm{Al}(\mathrm{OH})_{3} \\
\mathrm{Fe}(\mathrm{OH})_{3}\end{array}$ & $\mathrm{FeS}$ & $\begin{array}{c}\mathrm{Mn}(\mathrm{OH})_{2} \\
\mathrm{Fe}(\mathrm{OH})_{2}\end{array}$ \\
\hline $\begin{array}{c}\text { Filtrate composition } \\
\text { concerning of metals } \\
\text { presence } \\
\text { (liquid phase) }\end{array}$ & $\begin{array}{l}\mathrm{Fe}, \mathrm{Al}, \\
\mathrm{Zn}, \mathrm{Mn}\end{array}$ & $\begin{array}{l}\mathrm{Fe}, \mathrm{Al}, \\
\mathrm{Zn}, \mathrm{Mn}\end{array}$ & $\begin{array}{c}\mathrm{Fe}, \mathrm{Al}, \\
\mathrm{Mn}\end{array}$ & $\mathrm{Fe}, \mathrm{Mn}$ & $\mathrm{Fe}, \mathrm{Mn}$ & ------ \\
\hline
\end{tabular}




\subsection{Sorption of metals by bacterially produced iron sulphides}

Fig. 2 shows sorption of cadmium and zinc ions from model solutions by iron sulphides during 90 minutes by semi-continuous and discontinuous sorbents, when initial concentration of metal ions in model solutions was $50 \mathrm{mg} / \mathrm{L}$.

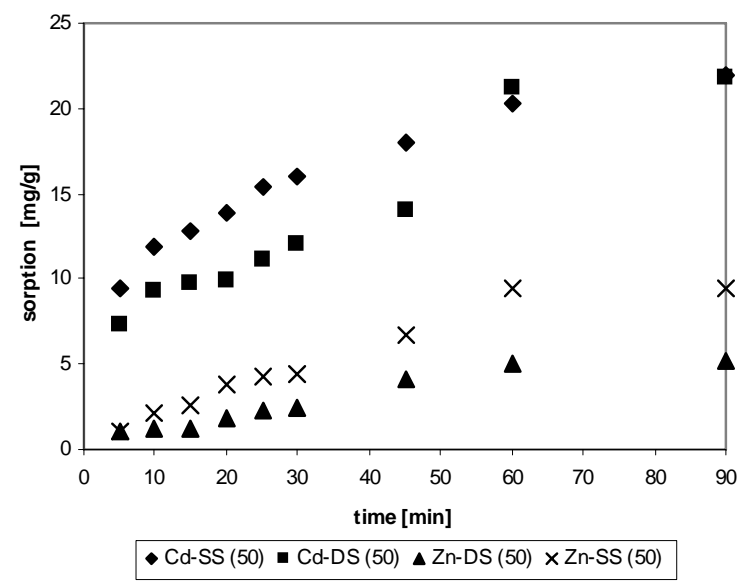

Fig. 2. Sorption of cadmium and zinc ions from model solutions.

The quantities of metal ions that iron sulphides captured from $100 \mathrm{~mL}$ of solution are in calculation on $1 \mathrm{~g}$ weights of dry the sorbent. We can see that the sorption value for cadmium after 90 minutes for semi-continuous sorbent (Cd-SS) is $21.96 \mathrm{mg} / \mathrm{g}$ and $21.83 \mathrm{mg} / \mathrm{g}$ for discontinuous sorbent (Cd-DS). Values of zinc sorption are $9.49 \mathrm{mg} / \mathrm{g}$ for semicontinuous sorbent (Zn-SS) and $5.22 \mathrm{mg} / \mathrm{g}$ for discontinuous sorbent (Zn-DS).

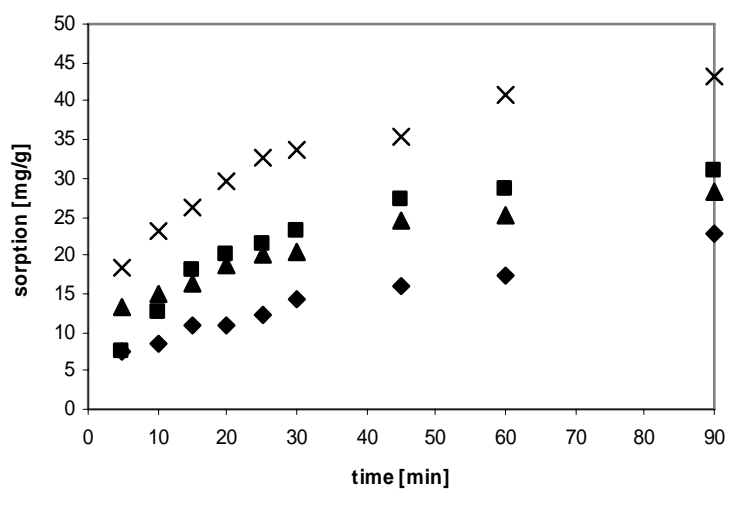

- Cd-SS (100) - Cd-DS (100) $\Delta$ Zn-DS (100) $\times$ Zn-SS (100)

Fig. 3. Sorption of cadmium and zinc ions from model solutions. 
Fig. 3 compares sorption of zinc and cadmium ions during 90 minutes by semicontinuous and discontinuous sorbents, when initial concentration of metal ions in model solutions was $100 \mathrm{mg} / \mathrm{L}$.

In this case the highest value was obtained for zinc sorption by semi-continuous sorbent (Zn-SS) $43.13 \mathrm{mg} / \mathrm{g}$ and the lower value belong to cadmium sorption by semicontinuous sorbent (Cd-SS) $22.75 \mathrm{mg} / \mathrm{g}$.

\subsection{Sorption by bio-modified brown coal}

Fig. 4 presents adsorption isotherms of copper and zinc adsorption by biomodified coal adsorbents. Experimental data were fitted by Langmuir equation. The correlation coefficient ranged from 0.96 to 0.99 .

Experimental results showed that maximum increase of metals uptake for biologically activated brown coal was achieved by the activation by Penicillium glabrum (sample S3), i.e. $8.8 \mathrm{mg} \mathrm{Cu(II)/g} \mathrm{of} \mathrm{sorbent} \mathrm{and} 14.3 \mathrm{mg} \mathrm{Zn}(\mathrm{II}) / \mathrm{g}$ of sorbent.
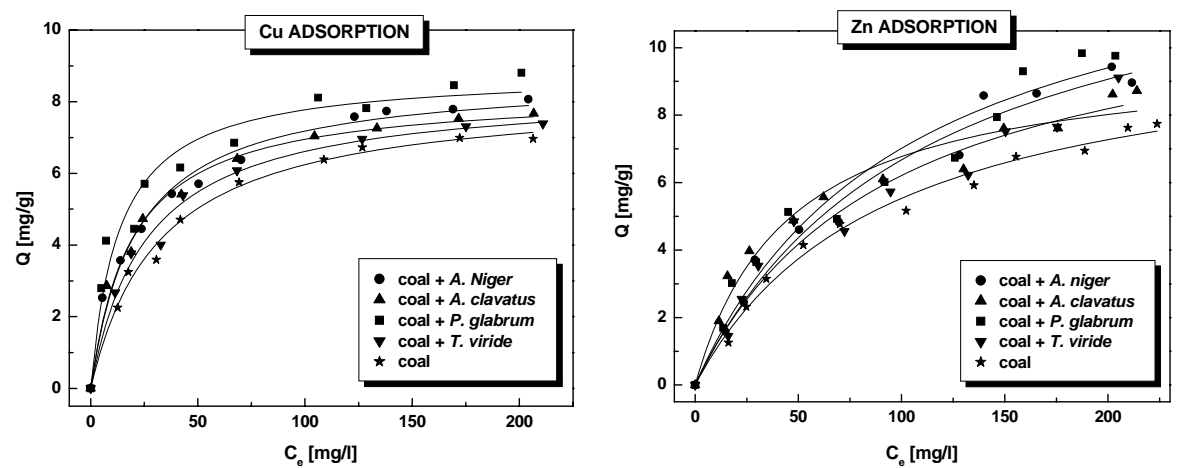

Fig. 4. Langmuir adsorption isotherms of $\mathrm{Cu}(\mathrm{A})$ and $\mathrm{Zn}(\mathrm{B})$ adsorption on brown coal treated by different microorganisms.

The results of adsorption experiments showed that selected type of sorbent preparation had positive influence on sorption properties of activated material and prepared sorbents had good affinity to selected metals. Obtained results confirmed that there is a possibility to prepare the sorbents by new non-conventional methods and the obtained results appear as promising for the research and development in utilisation of non-energetic coal.

\section{Conclusions}

The major metal ions in the AMD from the abandoned and flooded deposit of Smolnik (Slovak Republic) were $\mathrm{Fe}, \mathrm{Al}, \mathrm{Ca}$ and $\mathrm{Mg}$, among which $\mathrm{Fe}$ and $\mathrm{Al}$ were potentially valuable, while others such as $\mathrm{Cu}, \mathrm{Zn}$ and $\mathrm{Mn}$ were present as minor metals at significantly low concentrations. The value of $\mathrm{pH}$, contend of $\mathrm{Fe}, \mathrm{Al}, \mathrm{Zn}, \mathrm{Cu}, \mathrm{Mn}$ 
and Mg of AMD did not meet the effluent limitation of NV SR no. 296/2005 Z.z. Up to now AMD was not treated at the site.

Results of the AMD titration test document that the titration curve can be divided into four ranges (I to IV). Its show the different optimum $\mathrm{pH}$ for metals precipitation of each metal: for $\mathrm{Al}-\mathrm{pH} 5$; for $\mathrm{Cu}-\mathrm{pH} 6$; for $\mathrm{Zn}-\mathrm{pH} 7$; for $\mathrm{Fe}-\mathrm{pH}$ 8; for $\mathrm{Mn}-$ $\mathrm{pH}$ 9. The metals precipitation using $1 \mathrm{M} \mathrm{NaOH}$ confirms that was removed $97 \%$ of $\mathrm{Al}$ at $\mathrm{pH} 5 ; 99.9 \%$ of $\mathrm{Cu}$ at $\mathrm{pH} 6$; 99.9\% of $\mathrm{Zn}$ at $\mathrm{pH} 7 ; 99.9 \%$ of Fe at $\mathrm{pH} 8$ and $99.9 \%$ of $\mathrm{Mn}$ at $\mathrm{pH}$ 9. Metals removal by precipitation is possible up to $\mathrm{pH} 9$.

The study of the selective sequential precipitation and bio recovery of metals from aforementioned AMD was realized by the combination of the metals precipitation by the bacterially produced hydrogen sulphide and the precipitation of metals by sodium hydroxide at the various values of $\mathrm{pH}$ AMD. For the removal of $\mathrm{Cu}$ and $\mathrm{Zn}$ in the form of sulphides were received excellent results. Was not come to good results point of view of the $\mathrm{Fe}, \mathrm{Al}$ and $\mathrm{Mn}$ the selective precipitation, because was determined the co-precipitation of $\mathrm{Fe}$ and $\mathrm{Al}$ or $\mathrm{Fe}$ and $\mathrm{Mn}$.

Obtained results can be used for suggestion of technology for selective metal recovery from acid mine drainage from Smolnik. The base this technology will be the combination of chemical and biological agent application.

Acknowledgements: This work was supported by the Slovak Research and Development Agency under the contract No. APVV-51-027705 and bilateral project APVV SK-CZ-0105-07.

\section{References}

BALINTOVA, M., KOVALIKOVA, N.: Removal of heavy metals from acid mine drainage using adsorption methods. Proceedings of the $8^{\text {th }}$ International Scientific Conference Modern Management of Mine Producing, Geology and Environmental Protection SGEM 2008, Albena, 2008, 155-160.

BOONSTRA, J., VAN LIER, R., JANSSEN, G., DIKMAN, H., BUISMAN, C.J.N.: Biological Treatment of Acid Mine Drainage. Proceedings of the $13^{\text {th }}$ International Biohydrometallurgy Symposium, Biohydrometallurgy and the Environment toward the mining of the $21^{\text {st }}$ century II., IBS, Madrid, 1999, 559-566.

DEORKAR, N.V., TAVLARIDES, L.L.: Adsorption process for metal recovery from acid mine waste: The berkeley pit problem. Environ. Prog., 17, 1998, 120-125.

FOUCHER, S., BATTAGLIA-BRUNET, F., IGNATIADIS, I., MORIN, D.: Treatment by Sulfate-reducing bacteria of Chessy acid-mine drainage and metals recovery. Chem. Eng. Sci., 56, 2001, 1639-1645.

GARCIA SANCHEZ, A., ALAVAREZ AYUSO, E., JIMENEZ DE BLAS, O.: Sorption of heavy metals from industrial waste water by low-cost mineral silicates. Clay Miner., 34, 1999, 469-477.

JANKE, D.R., DIEBOLD, F.E.: Recovery of valuable metals from acid mine drainage by selective titration. Water Res., 17, 1983, 1639-1645.

KADUKOVA, J., VIRCIKOVA, E.: Minerálne biotechnológie III., Biosorpcia kovov z roztokov, VŠB TU Ostrava, 2003, ISBN 80-248-0244-9. 
KADUKOVA, J., STOFKO, M.: Environmentálne biotechnológie pre hutníkov, Equilibria, Košice, 2006a, ISBN 80-8073-496-8.

KADUKOVA, J., STOFKO, M.: Biosorption of heavy metals ions from aqueous solutions. Environmental Research Trends, Nova Publishers, 2006b, ISBN 160021-556-4.

KALIN, M., FYSON, A., WHEELER, N.W.: The chemistry of conventional and alternative treatment systems for the neutralization of acid mine drainage. Sci. Tot. Environ., 366, 2006, 395-408.

KONTOPOULS, A.: Acid Mine Drainage Control. In: CASTRO, S.H., VERGARA, F., SÁNCHES, M.A. (Eds.) Effluent Treatment in the Mining Industry. University of Concepcion, Chile, 1988, 57-118.

LUPTAKOVA, A., KUSNIEROVA, M., BEZOVSKA, M., FECKO, P.: The Selective Precipitation of Heavy Metals by Sulphate-reducing Bacteria. Proceedings of the $15^{\text {th }}$ International Biohydrometallurgy Symposium, Nereus Congress and Conferences, Athens, Greece, 2003, 665-672.

LUPTAKOVA, A., KUSNIEROVA, M., SLESAROVA, A.: Environmental risks and impact of old mine loads in the Slovak Republic. Proceedings of $2^{\text {nd }}$ International Conference on Environmental Research and Assessment, University of Bucharest, Centre for Environmental Research and Impact Studies, Bucharest, 2006, 254-257.

SKOUSEN, J., ROSE, A., GEIDEL, G., FOREMAN, J., EVANS, R., HELLIER, W.: A Handbook of Technologies for Avoidance and Reclamation of Acid Mine Drainage, Morgantown, Wv: National Mine Land Reclamation Center, West Virginia University, 1998.

TABAK, H.H., SCHARP, R., BURCKLE, J., KAWAHARAI, F.K., GOVIND, R.: Advances in biotreatment of acid mine drainage and biorecovery of metals: 1. Metal precipitation for recovery and recycle. Biodegradation, 14, 2003, 423436.

VEEKEN, A.H.M., RULKENS, W.H.: Innovative developments in the selective removal and reuse of heavy metals from waste-waters. Water Sci. Technol., 47, 2003, 9-16. 